\title{
Toxoplasmosis in pregnancy: test, treatment and outcome
}

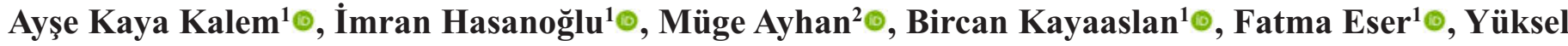 \\ Oğuz $^{3} \odot$, Filiz Yavuz Avşar ${ }^{4} \odot$, Rahmet Güner ${ }^{1} \odot$
}

${ }^{1}$ Department of Infectious Diseases and Clinical Microbiology, Ankara Yıldırım Beyazıt University, Ankara City Hospital, Ankara, Turkey

${ }^{2}$ Department of Infectious Diseases and Clinical Microbiology, Ankara City Hospital, Ankara, Turkey

${ }^{3}$ Department of Obstetrics and Gynecology, Ankara City Hospital, Ankara, Turkey

${ }^{4}$ Department of Obstetrics and Gynecology, Ankara Yıldırım Beyazıt University, Ankara City Hospital, Ankara, Turkey

\begin{abstract}
Objectives: The aim of this study was to share the results, follow-up, and treatment characteristics of our pregnant women who were followed-up with anti-Toxoplasma gondii Immunoglobulin (Ig) M positivity during pregnancy.

Methods: Anti-T. gondii IgM- and IgG-positive pregnant women were evaluated between 2014-2018. Demographic characteristics, treatment, and information about pregnancy were obtained from the electronic database. Pregnant women were divided into three groups; primary infection, no infection, and suspected infection in pregnancy. Primary and suspected infection in pregnancy were followed up congenital toxoplasmosis risky pregnancy. Fetal ultrasonography (USG), T. gondii DNA polymerase chain reaction (PCR) result in amniotic fluid were recorded.

Results: Twenty-four pregnant women with a mean age of 27.9 years were followed up. IgG avidity results were low in $37.5 \%(n=9)$, intermediate avidity in $8.3 \%(n=2)$, and high avidity in $54.2 \%(n=13)$ of pregnant women. Eleven $(45.9 \%)$ pregnant women had congenital toxoplasmosis risky pregnancy. Fetal USG was performed on ten pregnant women, and no signs of congenital toxoplasmosis were found. Amniocentesis was performed in $72.7 \%(\mathrm{n}=8)$ of the participants, and the amniotic fluid $T$. gondii DNA-PCR result was negative in all of them. Ten (90.9\%) pregnancies resulted in mature birth and one $(9.1 \%)$ resulted in miscarriage.

Conclusions: Anti-T. gondii IgM positivity is an indication of acute infection. But IgM can persist for years, and be false-positive in pregnancy. Therefore, additional tests are required, and leading to emotional distress and unnecessary interventions in pregnacy women. These results can aid in developing an approach to screening and diagnosis of $T$. gondii infection in pregnancy.

Keywords: Toxoplasmosis, pregnancy, avidity, congenital toxoplasmosis, T. gondii DNA polymerase chain reaction (PCR), fetal ultrasonography
\end{abstract}

$\mathrm{T}$ oxoplasmosis is a common parasitic disease worldwide and is caused by Toxoplasma gondii. Although it often causes a self-limited infection with asymptomatic or mild symptoms (such as fever, malaise, lymphadenopathy), it can have a severe course in immunosuppressive individuals (e.g., HIV). Besides, acute infection during pregnancy can pass to the fetus (congenital toxoplasmosis), miscarriage, premature birth, stillbirth may occur and may cause severe sequelae in live-born babies (such as mental 
retardation, chorioretinitis, epilepsy) $[1,2]$.

It is estimated that more than $30 \%$ of the world's population is infected with $T$. gondii. According to countries and regions, this rate varies between $10-80 \%$ due to differences in climate, nutrition, and hygiene habits $[3,4]$. In the United States, seropositivity has been reported to be $23 \%$ in adolescents and adults and $14 \%$ in women of childbearing age [2].

In a study investigating the prevalence of $T$. gondii in the world in 2009, our country was among the countries with a high prevalence $(30-60 \%)$ [4]. T. gondii IgG seropositivity was $24.6 \%$ in 17,751 women of childbearing age in Istanbul, Adana, Bursa, Kayseri, and Kocaeli, and $30.7 \%$ in a study including pregnant women from Denizli $[5,6]$. Seropositivity was $69.5 \%$ in pregnant women in Şanliurfa [7]. There are also regional differences in our country. It is noteworthy that these rates are similar to Italy, France, Finland, and Austria, where toxoplasma screening is mandatory [811]. The increase in the incidence of congenital toxoplasmosis presentation in newborns brings up a screening in the United States. Massachusetts and New Hampshire are two states that perform routine newborn screening [12]. In our country, information about screening needs to be clarified.

According to estimates obtained from regional data in the USA, 400-4,000 cases of congenital toxoplasmosis and 750 deaths have been reported annually. The fact that $50 \%$ of cases are food-borne makes toxoplasmosis the third leading cause of food-borne death in the United States [13]. Since congenital toxoplasmosis is a critical public health problem, the Centers for Disease Control and Prevention (CDC) has made recommendations to reduce the risk of congenital infection [14].

In our country, there is no recommendation for pregnancy screening in the Ministry of Health's Antenatal Care Management Guidelines for toxoplasmosis or the recommendations of the Turkish Perinatology Society $[15,16]$. In the age-related prevalence study performed in the province of Hatay, the estimation of the primary infection risk in pregnant women was found to be 6/1,000 [17]. The World Health Organization (WHO) estimated the incidence of congenital toxoplasmosis for Europe in 2013 to be 1.5 per 1,000 births [18].

Enzyme immunoassay methods that detect anti- $T$. gondii Immunoglobulin M (IgM) and immunoglobu- lin $\mathrm{G}(\operatorname{IgG})$ antibodies are frequently preferred in clinical practice for the laboratory diagnosis of toxoplasmosis due to their high sensitivity and ease of application. Anti-T.gondii IgM may remain positive for a long time in the peripheral blood. Therefore, additional tests such as IgG avidity, T. gondii DNA polymerase chain reaction (PCR) in amniotic fluid, and fetal ultrasonography (USG) are required to diagnose acute infection in pregnant women. Sometimes, the diagnosis is unclear even with these, and it is tried to be interpreted with the previous test results.

Our study aimed to interpret the test results of our pregnant women who were followed up with anti- $T$. gondii $\operatorname{IgM}$ and $\operatorname{IgG}$ positivity, their pregnancy followups, growth retardation in babies. Together with the seropositivity studies, these results were intended to shed light on the screening for toxoplasmosis in pregnancy and guide physicians in interpreting the tests.

\section{METHODS}

Pregnant women who applied to our Infectious Diseases and Clinical Microbiology outpatient clinic between 2014-2018 with anti-T. gondii IgM and IgG positivity were included in our study. The study was approved by Ankara City Hospital Ethical Committee. Demographic characteristics of the pregnant women, the treatment they received, and information about pregnancy were obtained from the electronic database. After gathering these data, information about the babies of the pregnant women was recorded. The ages of the babies, whether they had was growth retardation in their follow-ups.

The results were interpreted per the evaluation criteria of commercial kits. For anti- T. gondii IgM, $<0.8$ COI values were considered as negative, $\mathrm{COI}$ values between 0.8-0.999 as intermediate, $\geq 1 \mathrm{COI}$ values as positive, $<1 \mathrm{IU} / \mathrm{mL}$ values as negative for anti- $T$. gondii $\mathrm{IgG}$, values between 1-2.999 IU/mL as intermediate, $\geq 3 \mathrm{IU} / \mathrm{mL}$ values as positive and for IgG avidity test $<50$ index value as low avidity, index value between 50-50.9 as intermediate avidity, $\geq 60$ index value as high avidity.

The results were interpreted according to the gestational week and previous test results. Low avidity result was interpreted as primary infection in pregnancy. High avidity result was considered as no infec- 
tion in pregnancy if in the first 12 weeks of pregnancy, and as infection with undecidable timing- suspected infection- if after 12 weeks. Pregnant women who were evaluated as infection in pregnancy and suspected infection during pregnancy were followed up as congenital toxoplasmosis risky pregnancy. T. gondii DNA PCR and fetal USG results were recorded in the amniotic fluid of these pregnant women.

\section{Statistical Analysis}

Statistical analysis was performed using SPSS 18.0 version and Microsoft excel. Descriptive statistics were presented as frequency and percentages for categorical variables and as mean \pm standard deviation (SD) or median (minimum-maximum values) for continuous variables.

\section{RESULTS}

Twenty-four participants with a mean age of 27.9 years (20-38) were included in our study. There was a history of miscarriage in 3 and tuberculosis in one. There was no chronic disease or drug use. The median gestational week was 10.5 (range, 6-34) weeks. Nineteen pregnancies were in the first trimester, four were in the second trimester, and one was in the third trimester. None of the participants had any symptoms.
IgG avidity results were low in $37.5 \%(\mathrm{n}=9)$ of the pregnant women, intermediate avidity in $8.3 \%(n=2)$, high avidity in $54.2 \%(\mathrm{n}=13)$ (Fig. 1). Eleven $(84.6 \%)$ participants with high avidity were in the first trimester, and it was interpreted as no infection in pregnancy. Two $(15.4 \%)$ pregnant women were in the second trimester (15 and 16 weeks of gestation), and the timing for infection could not be determined (suspected infection). One of the pregnant women whose IgG avidity resulted as intermediate avidity was interpreted as a primary infection in pregnancy due to a 4fold increase in T. gondii IgG titer, and the other pregnant woman as no infection in pregnancy due to previous results. Since $88.9 \%(n=8)$ of the pregnant women with low avidity results had a primary infection in pregnancy and $11.1 \%(n=1)$ had results from their previous pregnancy, it was interpreted as no infection in pregnancy (Fig. 1).

Spiramycin 3gr/day dose was initiated for all participants who applied to our outpatient clinic with antiT. gondii IgM positivity, and an IgG avidity test was requested. Spiramycin treatment was discontinued in patients who were decided to have an infection before pregnancy.

Fetal ultrasonography results were available in $91.7 \%(n=22)$ of the participants, and no fetal anomaly was determined in any of them. Amniocentesis was performed in $37.5 \%(n=9)$ of the pregnant women,

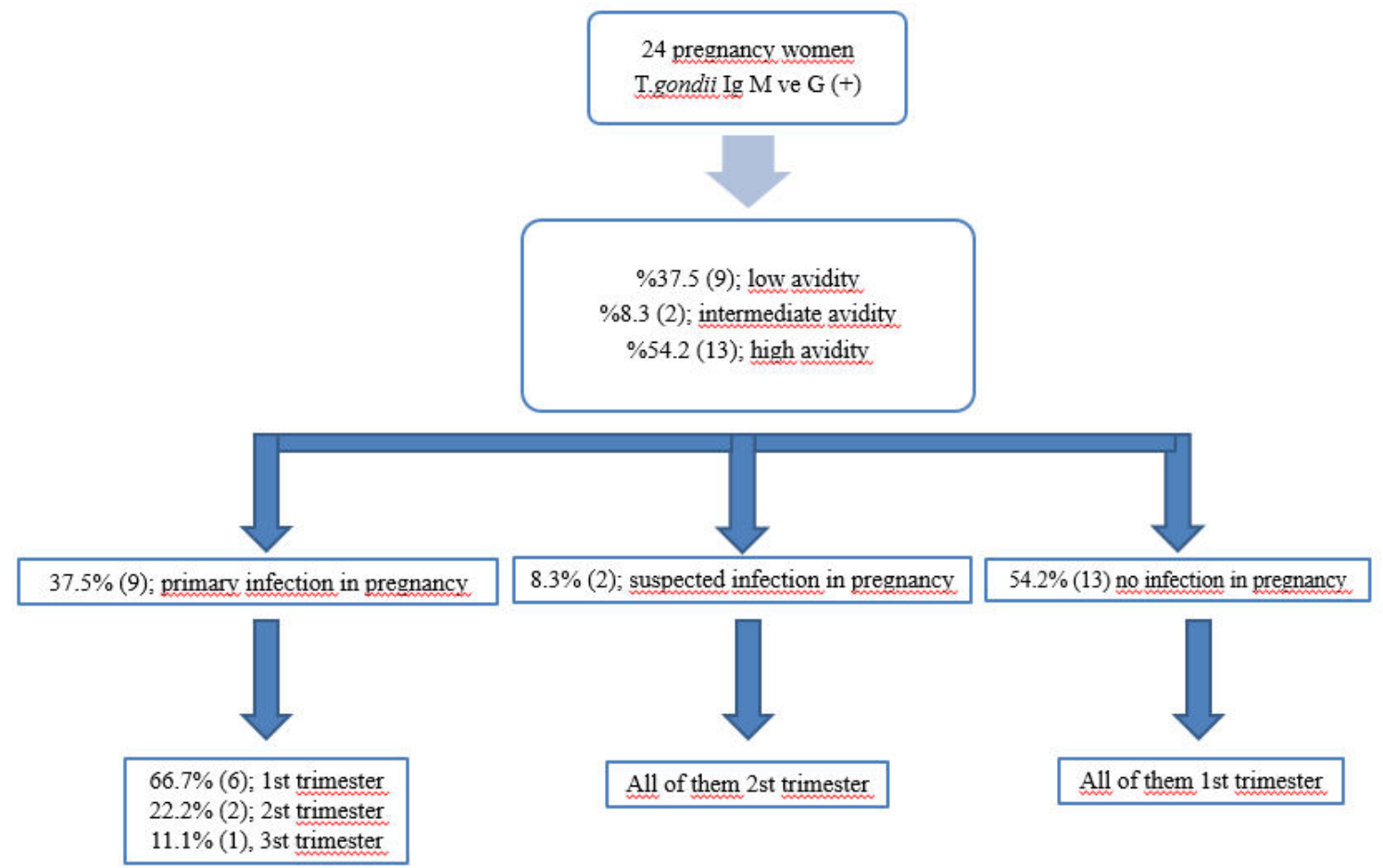

Fig. 1. Immunoglobulin (Ig) G avidity result and infection decision chart. 
and the T. gondii DNA PCR result in the amniotic fluid born mature. of all of them was negative. Considering the pregnancy outcomes, miscarriage developed in $12.5 \%$ (n $=3$ ). One of the pregnant women who had a miscarriage was diagnosed with a primary infection in pregnancy, and the other two were diagnosed with no infection in pregnancy. $87.5 \%(\mathrm{n}=21)$ of babies were
Eleven (45.9\%) pregnant women were congenital toxoplasmosis risky pregnancy (Table 1). Spiramycin treatment was continued in these pregnant women. The mean age of the pregnant women was 28 years. Of the pregnant patients with congenital toxoplasmosis risk, $54.5 \%(n=6)$ were in the first trimester,

\section{Table 1. Follow-up of congenital toxoplasmosis risky pregnant.}

\begin{tabular}{cccccccc}
\hline No & $\begin{array}{c}\text { Age } \\
\text { (years) }\end{array}$ & $\begin{array}{c}\text { Pregnancy } \\
\text { trimester }\end{array}$ & $\begin{array}{c}\text { IgG avidity } \\
\text { result }\end{array}$ & $\begin{array}{c}\text { Infection } \\
\text { definition }\end{array}$ & $\begin{array}{c}\text { Fetal } \\
\text { USG }\end{array}$ & $\begin{array}{c}\text { Amniotic fluid T. } \\
\text { gondii DNA PCR }\end{array}$ & $\begin{array}{c}\text { Pregnancy } \\
\text { termination }\end{array}$ \\
\hline 1 & 21 & II & Low & $\begin{array}{c}\text { Primary infection } \\
\text { in pregnancy }\end{array}$ & Normal & Negative & Born mature
\end{tabular}

\begin{tabular}{|c|c|c|c|c|c|c|c|}
\hline 2 & 24 & III & Low & $\begin{array}{l}\text { Primary infection } \\
\text { in pregnancy }\end{array}$ & Normal & No & Born mature \\
\hline 3 & 26 & I & Low & $\begin{array}{l}\text { Primary infection } \\
\text { in pregnancy }\end{array}$ & No & No & Born mature \\
\hline
\end{tabular}

\begin{tabular}{|c|c|c|c|c|c|c|c|}
\hline 4 & 27 & II & Low & $\begin{array}{l}\text { Primary infection } \\
\text { in pregnancy }\end{array}$ & Normal & Negative & Low \\
\hline 5 & 33 & I & Low & $\begin{array}{l}\text { Primary infection } \\
\text { in pregnancy }\end{array}$ & Normal & Negative & Born mature \\
\hline
\end{tabular}

\begin{tabular}{cccccccc}
6 & 34 & I & Low & $\begin{array}{c}\text { Primary infection } \\
\text { in pregnancy }\end{array}$ & Normal & No & Born mature \\
\hline 7 & 25 & I & Low & $\begin{array}{c}\text { Primary infection } \\
\text { in pregnancy }\end{array}$ & Normal & Negative & Born mature \\
8 & 25 & I & Low & $\begin{array}{c}\text { Primary infection } \\
\text { in pregnancy }\end{array}$ & Normal & Negative & Born mature \\
9 & 26 & I & Intermediate & $\begin{array}{c}\text { Primary infection } \\
\text { in pregnancy }\end{array}$ & Normal & Negative & Born mature \\
10 & 34 & II & High & $\begin{array}{c}\text { Suspected } \\
\text { infection in } \\
\text { pregnancy }\end{array}$ & Normal & Negative & Born mature \\
11 & 33 & II & High & $\begin{array}{c}\text { Suspected } \\
\text { infection in } \\
\text { pregnancy }\end{array}$ & Normal & Negative & Born mature \\
\hline
\end{tabular}

$\mathrm{IgG}=$ immunoglobulin $\mathrm{G}, \mathrm{PCR}=$ polymerase chain reaction, $\mathrm{USG}=$ ultrasonography 
$36.4 \%(n=4)$ were in the second trimester, and 9.1\% $(\mathrm{n}=1)$ were in the third trimester. In the IgG avidity results, $72.7 \%(\mathrm{n}=8)$ had low avidity, 9.1\% $(\mathrm{n}=1)$ had intermediate avidity, $18.2 \%(\mathrm{n}=2)$ had high avidity. Fetal ultrasonography was performed on ten pregnant women, and no signs of congenital toxoplasmosis were found. Amniocentesis was performed in $72.7 \%$ $(\mathrm{n}=8)$ of the pregnant women, and the amniotic fluid T.gondii DNA PCR result was negative in all of them. $90.9 \%(n=10)$ of pregnancies resulted in mature birth, and $9.1 \%(n=1)$ resulted in miscarriage. One of the babies was diagnosed with Bartter syndrome in the examinations performed due to growth retardation and died at sixth month due to aspiration pneumonia. The mean age of 9 living babies was $4.3(3-5)$. None of the babies had developmental delay.

\section{DISCUSSION}

There is no worldwide consensus for screening for toxoplasmosis during pregnancy. While there are countries that advocate screening all pregnant women, some do not advise screening. Geographical location, cultural practices, feeding habits, socioeconomic status significantly affect the prevalence of the disease. European countries lead the primary toxoplasmosis infections in the world. France reported the highest infection rates in pregnant women (54\%), while the remaining European countries reported lower infection rates $(46 \%)$ [20].

After acute infection, the IgM titer starts to rise on the fifth day and reaches its maximum level in 1-2 months. While IgM antibodies become negative before the sixth month in $25 \%$ of cases, they may remain positive for a year or even up to 2 years in other patients, depending on the sensitivity of the test method used [19]. IgG titer begins to be detected 1-2 weeks after acute infection and remains high for life [20]. In pregnant women with positive $T$. gondii $\operatorname{IgM}$ and $\operatorname{IgG}$ tests, it is recommended to perform an IgG avidity test to determine whether the infection is in the early or late stages [21]. However, since antibodies with low avidity can remain in the serum for months, infection in pregnancy may not always be present when a low avidity value is detected $[22,23]$. In such a case, laboratory diagnosis should be confirmed by PCR from amniotic fluid, and it should also be supported by clin- ical and ultrasonographic findings [22]. In interpreting serological tests, the time of requesting the tests is also important [24]. The high avidity result in the first trimester ensures the exclusion of infection. However, the examinations performed in the second and third trimesters make this decision difficult. In 20.8\% (5/24) of the pregnant women in our study, tests were requested in the second and third trimesters. This also made the interpretation of the tests complicated. In this case, previous serological examinations are beneficial in making the diagnosis. No infection in pregnancy was decided because $8.3 \%(2 / 24)$ of the pregnant women who applied to us due to toxoplasmosis had a previous serology analysis. There is no recommendation for routine screening in our country. Furthermore, there is no consensus among doctors due to the lack of a common follow-up plan. These challenges encountered in the interpretation of the tests cause unnecessary tests in pregnant women and increase the anxiety of the prospective parents due to the uncertainty of the baby's prognosis [25, 26]. A study in Italy stated that $51.3 \%$ of pregnant women had previous results, making decision-making much easier [27]. They argued that more detailed studies on the tests used in screening policies should be done [27].

In pregnant women diagnosed with acute toxoplasmosis, the use of fetal USG is recommended after serological tests. Neurological anomalies (hydrocephalus, ventriculomegaly, and intracerebral calcifications), splenomegaly, congenital nephrosis, and ascites can be detected in fetal USG [28]. In our study, fetal USG was performed in $90.9 \%$ of pregnant women with congenital toxoplasmosis risk, and no finding suggestive of toxoplasmosis was detected in any of them. In the study of Italy, at least one finding suggestive of congenital toxoplasmosis was found in $10.4 \%$ of fetuses [27]. As the result of a multicenter study in France, the rate of an anomaly in fatal USG was reported as $4.2 \%$. [29].

Amniocentesis is recommended at the earliest 18 th week in pregnant women diagnosed with acute infection during pregnancy. T. gondii DNA PCR in amniotic fluid has a positive predictive value close to $100 \%$ in determining fetal infection [30]. In the study of Greco et al. [31], T. gondii DNA PCR was found to be $6 \%$ positive in amniotic fluid during primary infection. In a report from our country in 2021, T. gondii DNA PCR positivity in amniotic fluid was reported as 
$16.7 \%(1 / 6)$. This condition has been associated with initiating treatment late in pregnancy [32]. In our study, eight pregnant women underwent amniocentesis, and the $T$. gondii DNA PCR result in amniotic fluid was negative in all of them. This result supports the ultrasound findings showing that there is no fetal involvement.

Fetal transmission generally occurs at the rate of $29 \%$ (95\% CI $25-33)$, while it is $6 \%$ at 13 weeks of gestation and $72 \%$ at 36 weeks of gestation. Congenital infection was determined in a pregnant woman who had seroconversion at 24-30 weeks of gestation, and it was reported that the incidence of her findings would be the highest (10\%) [33]. As a result of the meta-analysis performed in 2014, the infection rate in the third trimester was 32\% [24]. In the study of Avelino et al. [34], the rate of congenital toxoplasmosis was reported to be as high as $56 \%$ in women with suspected infection. However, it was reported that high rates might be due to delayed first-trimester screening of pregnant women [27]. This indicates the importance of antenatal screening time. Apart from this, the rates were reported to be much lower, such as $0.8-7 \%$, in studies performed in pregnant women with Anti-T. gondii $\operatorname{IgM}(+) / \operatorname{IgG}(+)$ and low avidity [31, $35,36]$. Our study considered no fetal involvement since there was no problem in both the intrauterine tests and the follow-up of the babies after birth. Early treatment in pregnancy reduces fetal transmission by $50 \%[37,38]$. In our study, $54.5 \%(6 / 11)$ of pregnant women with congenital toxoplasmosis risk were in the first trimester, and all of them were initiated with spiramycin, which may be the reason why we did not see any signs of congenital involvement.

Some findings of fetal involvement of congenital toxoplasmosis can be easily missed at birth. Most babies develop late symptoms months after birth, such as chorioretinitis, seizures, mental retardation, and motor or cerebellar dysfunction. Furthermore, associations between congenital infection and sensorineural hearing loss, congenital nephrosis, hematological abnormalities, hepatosplenomegaly, various endocrinopathies, and myocarditis have been demonstrated [39]. We obtained information from the mothers about the outcomes of the babies and found that there was no developmental delay

One of the pregnancies diagnosed as primary infection in pregnancy ended in miscarriage. In the fetal
USG performed in this pregnancy, no fetal anomaly was found to suggest congenital toxoplasmosis. Moreover, T. gondii DNA PCR was negative in amniotic fluid. Therefore, the miscarriage developed is not associated with toxoplasmosis, but it cannot be said clearly because the miscarriage material is not screened for toxoplasmosis.

\section{Limitations}

Our study has limitations such as being retrospective, the small number of patients, the fact that the miscarried baby was not examined in terms of toxoplasmosis, and it does not provide clear data on seroprevalence. However, it gives information about congenital transmission as it includes the long-term results of babies. A large-scale study has not yet been performed to determine the rate of congenital toxoplasmosis in Turkey [11]. Leading these studies was critical in justifying establishing a consensus on pregnancy screening and follow-up. It is also hoped that it will aid physicians in interpreting serological test results.

\section{CONCLUSION}

Toxoplasmosis is a preventable infection that affects millions of women and their children. The difficulty in interpreting serological results in the outpatient clinic causes significant difficulties for us, the physicians, and the mother and father-to-be with the stress it creates. Babies who are not correctly diagnosed and treated for congenital toxoplasmosis are at risk for lifelong brain and ocular abnormalities [20]. Considering the rates in our country, it is vital to evaluate women of childbearing age who are planning a pregnancy and pregnant women in terms of acute toxoplasmosis. In particular, systematic serological screening of pregnant women by establishing a national program will ensure that the cost-effectiveness of the screening is evaluated, and the problems experienced in diagnosis and follow-up will be minimized.

\section{Authors' Contribution}

Study Conception: RG, AKK; Study Design: AKK, İH; Supervision: AKK, İH, MA; Funding: N/A; Materials: FYA; Data Collection and/or Processing: AKK, MA, FE; Statistical Analysis and/or Data Inter- 
pretation: AKK, BK; Literature Review: YO; Manuscript Preparation: AKK, RG and Critical Review: AKK, FE, RG, YO.

\section{Conflict of interest}

The authors disclosed no conflict of interest during the preparation or publication of this manuscript.

\section{Financing \\ The authors disclosed that they did not receive any grant during conduction or writing of this study.}

\section{REFERENCES}

1. Saadatnia G, Golkar M. A review on human toxoplasmosis. Scand J Infect Dis 2012; 44: 805-14.

2. National Center for Health Statistics. Plan and operation of the third National Health and Nutrition Examination Survey, 198894. Hyattsville, MD: US Department of Health and Human Services, Public Health Service, CDC, 1994. (Monthly vital statistics report; series 1, no. 32).

3. Montoya JG, Liesenfeld O. Toxoplasmosis. Lancet 2004;363:1965-76.

4. Pappas G, Roussos N, Falagas ME. Toxoplasmosis snapshots: global status of Toxoplasma gondii seroprevalence and implications for pregnancy and congenital toxoplasmosis. Int J Parasitol 2009;39:1385-94.

5. Akyar I. Seroprevalence and coinfections of Toxoplasma gondii in childbearing age women in Turkey. Iranian J Publ Health 2011;40:63-7.

6. Karabulut A, Polat Y, Türk M, Balcı YI. Evaluation of rubella, Toxoplasma gondii, and cytomegalovirus seroprevalences among pregnant women in Denizli province. Turk J Med Sci 2011;41:159-64.

7. Tekay F, Özbek E. [The Seroprevalence of Toxoplasma gondii in women from Sanluurfa, a province with a high raw meatball consumption]. Türkiye Parazitol Derg 2007;31:176-79. [Article in Turkish]

8. De Paschale M, Agrappi C, Manco MT, Cerulli T, Clerici P. Implementation of screening for Toxoplasma gondii infection in pregnancy. J Clin Med Res 2010;2:112-6.

9. Villena I, Ancelle T, Delmas C, Garcia P, Brezin AP, Thulliez $\mathrm{P}$, et al.; Toxosurv network and National Reference Centre for Toxoplasmosis. Congenital toxoplasmosis in France in 2007: first results from a national surveillance system. Euro Surveill 2010;15:19600.

10. Aspöck H, Pollak A. Prevention of prenatal toxoplasmosis by serological screening of pregnant women in Austria. Scand J Infect Dis 1992; 84 (Suppl):32-7.

11. Mumcuoğlu İ, Toyran A, Çetin F, Alaca Coşkun F, Baran I, Aksu N, et al. [Evaluation of the Toxoplasmosis seroprevalence in pregnant women and creating a diagnostic algorithm]. Mikrobiyol Bul 2014;48:283-91. [Article in Turkish]

12. McLeod R, Kieffer F, Sautter M, Hosten T, Pelloux H. Why prevent, diagnose and treat congenital toxoplasmosis? Mem Inst Oswaldo Cruz. 2009; 104:320-44.

13. Jones JL, Dargelas V, Roberts J, Press C, Remington JS, Montoya JG. Risk factors for Toxoplasma gondii infection in the United States. Clin Infect Dis 2009;49:878-84.

14. Lopez A, Dietz VJ, Wilson M, Navin TR, Jones JL. Preventing congenital toxoplasmosis. MMWR Recomm Rep. 2000;49(RR-2):59-68.

15. "Doğum Öncesi Bakım Yönetim Rehberi” T.C. Sağlık Bakanlığı Türkiye Halk Sağlığı Kurumu. Yayın No: 924. Ankara, 2014. Available at: https://sbu.saglik.gov.tr/Ekutuphane/kitaplar/dogumonubakim.pdf. Accessed Kasim 13. 2021.

16. Müngen E. Gebelikte toksoplazma taramas1. Perinatoloji Dergisi 2010;18:69-71.

17. Çetin M, Çetin Ş. [Age-related prevalence of toxoplasmosis among pregnant women in Hatay: estimation depending on model]. Mikrobiyol Bul 2017;51:361-9. [Article in Turkish]

18. Torgerson PR, Mastroiacovo P. The global burden of congenital toxoplasmosis: a systematic review. Bull World Health Organ 2013;91:501-8.

19. Gras L, Gilbert RE, Wallon M, Peyron F, Cortina-Borja M. Duration of the IgM response in women acquiring Toxoplasma gondii during pregnancy: implications for clinical practice and cross-sectional incidence studies. Epidemiol Infect 2004;132:541-8.

20. Hampton MM. Congenital Toxoplasmosis: a review. Neonatal Netw 2015;34:274-8.

21. Nascimento FS, Suzuki LA, Rossi CL. Assessment of the value of detecting specific IgA antibodies for the diagnosis of a recently acquired primary Toxoplasma infection. Prenat Diagn 2008;28:749-52.

22. Montoya JG, Liesenfeld O, Kinney S, Press C, Remington JS. VIDAS test for avidity of Toxoplasma-specific immunoglobulin $\mathrm{G}$ for confirmatory testing of pregnant women. J Clin Microbiol 2002;40:2504-8.

23. Remington JS, Thulliez P, Montoya JG. Recent developments for diagnosis of toxoplasmosis. J Clin Microbiol 2004;42:941-5. 24. Li XL, Wei HX, Zhang H, Peng HJ, Lindsay DS. A meta analysis on risks of adverse pregnancy outcomes in Toxoplasma gondii infection. PLoS One 2014;9:e97775.

25. Khoshnood B, De Vigan C, Goffinet F, Leroy V. Prenatal screening and diagnosis of congenital toxoplasmosis: a review of safety issues and psychological consequences for women who undergo screening. Prenat Diagn 2007;27:395-403.

26. Liesenfeld O, Montoya JG, Tathineni NJ, Davis M, Brown BW Jr, Cobb KL, et al. Confirmatory serologic testing for acute toxoplasmosis and rate of induced abortions among women reported to have positive Toxoplasma immunoglobulin $\mathrm{M}$ antibody titers. Am J Obstet Gynecol 2001;184:140-5.

27. Donadono V, Saccone G, Maruotti GM, Berghella V, Migliorini S, Esposito G, et al. Incidence of toxoplasmosis in pregnancy in Campania: a population-based study on screening, treatment, and outcome. Eur J Obstet Gynecol Reprod Biol 2019;240:31621.

28. Montoya JG, Remington JS. Management of Toxoplasma 
gondii infection during pregnancy. Clin Infect Dis 2008;47:55466.

29. Mandelbrot L, Kieffer F, Sitta R. Laurichesse-Delmas H, Winer N, Mesnard L, et al. Prenatal therapy with pyrimethamine + sulfadiazine vs spiramycin to reduce placental transmission of toxoplasmosis: a multicenter, randomized trial. Am J Obstet Gynecol 2018;219:386.e1-9.

30. Serranti D, Buonsenso D, Valentini P. Congenital toxoplasmosis treatment. Eur Rev Med Pharmacol Sci 2011;15:193-8.

31. Greco P, Vimercati A, Angelici MC, Carbonara S, Doria G, Nappi L, et al. Toxoplasmosis in pregnancy is still an open subject. J Perinat Med 2003;31:36-40.

32. Barsan Kaya T, Sürmeli Onay Ö, Aydemir Ö, Güneş D, Tekin AN. Toksoplazma Seropozitifliği Olan Anne Bebeklerinin Klinik Bulguları: Tek Merkez Deneyimi. IV. Başkent Pediatri Günleri, Ankara, Türkiye, 16 - 17 Nisan 2021, ss.38-39.

33. Dunn D, Wallon M, Peyron F, Petersen E, Peckham C, Gilbert R. Mother-to-child transmission of toxoplasmosis: risk estimates for clinical counselling. Lancet 1999;353:1829-33.

34. Avelino MM, Amaral WN, Rodrigues IM, Rassi Ar, Gomes MBF, Costa TL, et al. Congenital toxoplasmosis and prenatal care state programs. BMC Infect Dis 2014;18:33.

35. Findal G, Stray-Pedersen B, Holter EK. Persistent low toxoplasma IgG avidity is common in pregnancy: experience from antenatal testing in Norway. PLoS One 2015;10: e0145519.

36. Hotop A, Hlobil H, Gross U. Efficacy of rapid treatment initiation following primary Toxoplasma gondii infection during pregnancy. Clin Infect Dis 2012;54:1545-52.

37. McAuley J, Boyer KM, Patel D, Mets M, Swisher C, Roizen $\mathrm{N}$, et al. Early longitudinal evaluation of treated infants and children of untreated historical patients with congenital toxoplasmosis: the Chicago Collaborative Treatment Trial. Clin Infect Dis 1994;18:38-72.

38. Foulon W, Villena I, Stray-Pedersen B, Decoster A, Lappalainen M, Pinon JM, et al. Treatment of toxoplasmosis during pregnancy: a multicenter study of impact on fetal transmission and children's sequelae at age 1 year. Am J Obstet Gynecol 1999;180(2 Pt 1):410-5.

39. Gomella T, Cunningham MD, Eyal FG. Neonatology: Management, Procedures, On-Call Problems, Diseases, and Drugs. 7th ed. New York, NY: McGraw-Hill Education; 2013. 